\title{
Responses of Fecal Coliform in Streamwater to Four Graz- ing Strategies
}

\author{
A.R. TIEDEMANN, D.A. HIGGINS, T.M. QUIGLEY, H.R. SANDERSON, AND D.B. MARX
}

\section{Abstract}

Concentrations and loadings (output, number day ${ }^{-1} \mathbf{k m}^{-2}$ ) of fecal coliform (FC) indleator bacteria were measured from 1979 through 1984 in streamflow from 13 forested watersheds under the following range management strategies: (A) no grazing; (B) graxing without management for livestock distribution; (C) grazing with management to obtain livestock distribution, and (D) graxing with management to obtain livestock distribution and cultural practices to increase forage. Both $F C$ concentrations (number $/ 100 \mathrm{ml}$ ) and instantaneous loadings differed significantly among strategies, seasons, and water years. Differences among strategies for mean concentrations were $A<C=B<D$. For instantaneous loadings, significant differences were $\mathbf{A}<\mathbf{C}, \mathbf{B}$ or $\mathbf{D}$; and $C<D$. FC concentrations were the same for winter and for snowmelt runoff seasons but concentrations of both were significantly lower than during the summer period. Loadings were different for each season with winter<summer<snowmelt runoff. A definite relationship was established between the presence of cattle on the pastures and FC concentrations. Elevated FC counts in strategy $D$ watersheds and loadings in excess of $10^{3}$ organisms $\mathrm{dny}^{-1} \mathrm{~km}^{-2}$ in the winter season provide evidence that organisms live into and through the winter period in animal feces, sediment, and soil. Results provide evidence that livestock removal may not provide an immediate solution to elevated levels of FC in streamwater.

Key Words: bacterial water contamination, water quality, nonpoint source pollution, grazing systems

Bacterial contamination of forest and rangeland surface waters by livestock is an important land management issue; there is concern for both onsite and downstream use of streamwater from wildlands. Fecal coliform organisms (FC), primarily, Eschericia coli, in streamwater indicates contamination by warm-blooded animals (U.S. Environmental Protection Agency 1976). The concentration (number $/ 100 \mathrm{ml}$ ) of these organisms in streamwater is the currently accepted means of assessing the bacterial quality. For example, water quality standards in Oregon require less than a log mean of 200 fecal coliform organisms $/ 100 \mathrm{ml}$ of water based on at least 5 samples collected within a 30-day period (State of Oregon 1984). Also, no more than $10 \%$ of the samples can exceed $400 \mathrm{FC}$ organisms / $100 \mathrm{ml}$. Although not a pathogen, the presence of this bacterium indicates the potential for pathogens to also be present. At FC densities from 1 to $200 / 100 \mathrm{ml}$, the percentage of occurrence of Salmonella disease organisms is $27.6 \%$ (Geldreich 1970). Occurrence of Salmonella increases to $85.2 \%$ at FC levels of 201 to $2,000 / 100 \mathrm{ml}$ and to $98.1 \%$ when the levels are over $2,000 \mathrm{FC} / 100$ $\mathrm{ml}$. The use of FC concentrations as an indication of the biological quality of wildland streams has shortcomings despite its acceptance as a water quality standard. According to Bohn and Buckhouse (1985), FC organisms may not be suitable indicators for the presence of Giardia spp., a protozoan found in wildland streams.

Several studies have shown a direct relationship between cattle grazing and fecal coliform levels in a streamwater (Coltharp and Darling 1973, Skinner et al. 1974, Doran and Linn 1979, Gary et al. 1983). In these studies, grazing increased FC organism counts as much as 10 times; levels were apparently dependent on livestock density (Gary et al. 1983), and elevated counts may remain high for

\footnotetext{
Authors are principal range scientist, Pacific Northwest Research Station, La Grande, Oregon 97850; hydrologist, Chequamegon National Forest, Park Falls, Wisconsin 54552; range economist and principal range scientist, Pacific Northwest Research Station, La Grande, Oregon 97850; and associate professor, Agricultural Statistics, University of Arkansas, Fayetteville 72701.

Manuscript accepted 5 January 1987
}

many months after cattle are removed (Stephenson and Street 1978, Jawson et al. 1982). Some viable FC organisms remain in animal wastes for up to 1 year (Clemm 1977); consequently, there is a potential source of organisms to enter streamwater long after the animals have left the watershed. Fecal coliform organisms may survive up to 2 weeks and fecal streptococcus up to 3 weeks in soil (Van Donsel et al. 1967); both will survive up to 6 weeks in surface waters (Clemm 1977). Sediments also serve as a reservoir of FC and Salmonella organisms (Kunkle 1970, Van Donsel and Geldreich 1971, Stephenson and Rychert 1982).

Although there are many studies on the response of $\mathrm{FC}$ indicator bacteria in streamwater to the presence of grazing livestock, information is sparse for effects of various grazing systems or intensities (strategies) of range management on FC levels. Skinner et al. (1984) compared bacterial water quality between deferred-rotation and continuous grazing systems in Wyoming. When differences in FC concentrations between grazing systems were significant, levels were greater for deferred rotation. Stocking rate of the deferred rotation was $1.58 \mathrm{ha} / \mathrm{AUM}$ compared to $1.34 \mathrm{ha} / \mathrm{AUM}$ for continuous. Implementation of intensified grazing management practices carries the risk of adverse biological stream pollution effects, and managers need to understand the impacts of intensified grazing management on bacterial water quality.

The primary objective of this study was to determine the responses of FC bacteria in streamwater of 13 forested range watersheds to 4 grazing management strategies. The secondary objective was to evaluate seasonal and yearly responses to different grazing strategies.

\section{Background}

The Oregon Range Evaluation Project (EVAL) was established in 1976 to implement known range management techniques and to evaluate their impacts on range and associated resources. Water quality was one of the major associated resources studied during the project (Sanderson and Quigley 1984).

Four intensities of range management or strategies formed the basis for evaluations in this study:

Strategy A. Control-no grazing.

Strategy B. Grazing with no attempt to attain uniform livestock distribution throughout a pasture.

Strategy C. Management of grazing to attain uniform livestock distribution throughout a pasture by using fences and water developments.

Strategy D. Management of intensive grazing to maximize livestock production with multiple-use considerations. Includes practices to attain uniform livestock distribution and to improve forage production by using such cultural practices as seeding, fertilizing, and forest thinning.

\section{Location and Characteristics of Watersheds}

The EVAL studies are near John Day in Grant County, Oregon, and encompass approximately 347,000 acres on 19 Forest Service grazing allotments and 21 private ranches. The 13 study watersheds were in the northern part of the Malheur National Forest within grazing allotments managed under the EVAL project.

Watersheds ranged in size from 1.2 to $18.1 \mathrm{~km}^{2}$ and in mean 
Table 1. Range management stratery, graxing system, and characteristics of the $\mathbf{1 3}$ study watersheds.

\begin{tabular}{|c|c|c|c|c|c|c|c|c|}
\hline \multirow[b]{2}{*}{ Watershed } & \multicolumn{2}{|c|}{ Range management strategy } & \multirow{2}{*}{$\begin{array}{l}\text { Grazing } \\
\text { system } 1\end{array}$} & \multirow[b]{2}{*}{ Ecosystem ${ }^{2}$} & \multirow{2}{*}{$\begin{array}{c}\text { Drainage area } \\
\left(\mathrm{km}^{2}\right)\end{array}$} & \multicolumn{3}{|c|}{ Elevation (m above $\mathrm{msl}$ ) } \\
\hline & Pre-EVAL & EVAL & & & & Min & Mean & $\operatorname{Max}$ \\
\hline Big Creek & (A) & $\mathbf{A}$ & none & FS & 5.2 & 1817 & 1992 & 2225 \\
\hline Blackey Creek & (B) & $\mathbf{A}$ & none & $\mathbf{L}$ & 2.3 & 1599 & 1932 & 2344 \\
\hline Caribou Creek & (B) & C & DR & PP & 6.3 & 1238 & 1493 & 1905 \\
\hline East Donaldson Creek & (B) & C & DR & $\mathbf{L}$ & 4.1 & 1235 & 1478 & 1732 \\
\hline East Little Butte Creek & (B) & C & DR & $\mathbf{L}$ & 3.0 & 1199 & 1487 & 2204 \\
\hline Flood Meadow & (C) & $\mathbf{D}$ & $\mathbf{R R}$ & $\mathbf{L P} / \mathbf{M M}$ & 18.1 & 1553 & 1678 & 1892 \\
\hline Keeney Meadow & (C) & D & DR & $\mathbf{M M} / \mathbf{P P}$ & 12.7 & 1638 & 1690 & 1862 \\
\hline Lake Creek & (B) & A & none & $\mathbf{L}$ & 1.2 & 1532 & 1611 & 1732 \\
\hline Little Boulder Creek & (B) & $\mathrm{C}$ & DR & $\mathbf{L}$ & 6.0 & 1453 & 1786 & 2301 \\
\hline Ragged Creek & (B) & $\mathbf{A}$ & none & $\mathrm{L}$ & 8.8 & 1193 & 1559 & 1908 \\
\hline Tinker Creek & (B) & $\mathrm{D}^{3}$ & DR & L & 4.4 & 1472 & 1611 & 1886 \\
\hline West Donaldson Creek & (B) & $\mathrm{C}$ & DR & $\mathbf{L}$ & 3.9 & 1235 & 1450 & 1659 \\
\hline West Little Butte Creek & (B) & B & SL & $\mathbf{L}$ & 4.6 & 1199 & 1532 & 2277 \\
\hline
\end{tabular}

IDR = Deferred rotation

SL $=$ Season long

$\mathbf{R R}=\mathbf{R e s t}$ rotation

2FS = Fir spruce

L = Larch

MM = Mountain meadow

$\mathbf{P P}=$ Ponderosa pine

$\mathbf{L P}=$ Lodgepole pine

${ }^{3}$ Strategy $\mathrm{D}$ at Tinker Creek was attained in water year 1981; all other strategies were attained in water year 1979.

elevation from 1,450 to $1,992 \mathrm{~m}$ (Table 1). Predominant vegetative habitats were mountain meadow, western larch (Larix occidentalis), fir-spruce (Abies lasiocarpa-Picea engelmannii), ponderosa pine (Pinus ponderosa), and lodgepole pine (Pinus contorta). The range management strategy prior to implementation of EVAL and the strategy achieved during the project on each watershed are also shown in Table 1. The grazing system imposed on each watershed is indicated, but the emphasis will be on strategy effects because more than 1 grazing system was used to achieve a given range management strategy. In most cases, the study watersheds were part of a larger fenced pasture, so cattle were not restricted to watershed area.

Climate is typical of eastern Oregon. Data from the Austin, Ore., weather station indicate that most $(70 \%)$ of the precipitation is received as snow between November and April (National Oceanic and Atmospheric Administration 1984). Average annual temperature of the area is $2^{\circ} \mathrm{C}$ with monthly means of $-9^{\circ} \mathrm{C}$ in January and $14^{\circ} \mathrm{C}$ in July. Daily maxima will exceed $32^{\circ} \mathrm{C}$ in the summer. During the winter, daily minima below $-18^{\circ} \mathrm{C}$ are not uncommon.

Runoff patterns are similar to those reported for other watersheds in eastern Oregon and Washington (Helvey et al. 1976, Fowler et al. 1979). The annual hydrograph is dominated by snowmelt runoff that begins in lower elevation watersheds in March and in higher elevation watersheds in mid-May. Peak discharge occurs from mid-April to early June, depending on elevation and aspect of watersheds. Flows diminish throughout the summer with lowest levels occurring in August and September. Peak flows on the study watersheds ranged from 5.7 to 634 liters sec $\mathrm{km}^{-2}\left(0.5\right.$ to $55 \mathrm{ft}^{3}$ $\mathrm{sec}^{-1} \mathrm{mi}^{-2}$; ; late summer minimum flows ranged from 0.03 to 4.8 liters $\sec ^{-1} \mathrm{~km}^{-2}\left(0.003\right.$ to $\left.0.42 \mathrm{ft}^{3} \mathrm{sec}^{-1} \mathrm{mi}^{-2}\right)$.

\section{Methods}

Grab samples of streamflow were collected from each watershed at 3- to 6-week intervals from October 1978 to September 1984 using sterile plastic bottles. Samples were transported to the laboratory and analyzed within 8 hours of collection. Samples collected between June and September 1983 and 1984 were placed on ice in a cooler. Samples collected at other times during these 2 years were not packed in ice. Efforts were made to keep samples collected from June through September, between 1979 and 1982, cool and out of the sun, but we were concerned that the failure to ice samples may have affected FC survival. The lack of icing did not concern us during late fall, winter, and early spring when ambient tempera- tures were low $\left(<5^{\circ} \mathrm{C}\right)$. During summer 1984, we sampled to determine if there were differences between iced and uniced samples and to determine if a relationship could be established between the 2 sample handling procedures. On 6 sampling occasions between 1 July and 30 September 1984, we collected paired samples at each site. One sample was placed on ice in a cooler; the other left uniced in a cardboard box.

Samples were analyzed using the membrane filter technique and commercial membrane filter culture medium (Rand et al. 1975). Culturing was done in tight-fitting dishes on an aluminum block incubator with temperature control within $0.2^{\circ} \mathrm{C}$ of that required. Only distinct blue colonies were counted. When high counts were anticipated, samples were diluted. Concentrations are expressed as the number of colonies/ $100 \mathrm{ml}$.

Fecal coliform concentrations were normalized using a $\log _{10}$ transformation. To account for zero values, the transformation was done using FC concentration +1 . Concentration data are presented as geometric means; the means were determined by taking the antilog of the $\log _{10}$ mean and subtracting one.

Concentrations alone do not provide a complete picture of FC behavior. The number of FC flushed from a watershed depends on both concentration and flow. During snowmelt runoff, if FC are present, dilution can mask the carryover effect from livestock use the previous season. Because flows per unit area vary greatly among watersheds and seasons, loadings were calculated to provide an additional perspective of $F C$ response to different grazing management strategies. Loadings of FC were determined by multiplying the concentration (number $/ 100 \mathrm{ml}$ ) by the quantity of flow (liters/sec) at the time the sample was collected. These instantaneous loadings were then expressed as number day ${ }^{-1} \mathrm{~km}^{-2}$. Loading data were also normalized using a $\log _{10}$ transformation.

Both FC concentration and loading data were checked for normality by plotting frequency distributions. These were determined by converting data from each watershed to standardized $Z$-values (Snedecor and Cochran 1967) and combining across watersheds.

A paired $t$-test was used to determine if there were significant differences in the counts of FC between iced and uniced samples. Polynomial regression was used to determine the appropriate relationship of iced to uniced samples to provide an adjustment factor.

Concentration and loading data were analyzed as a split-plot in time with strategies and watershed within strategy as the main plot factor and main plot error term, respectively, and seasons and water years as the time factors (Steel and Torrie 1960). Three seasons were identified: summer, snowmelt runoff, and winter. The 

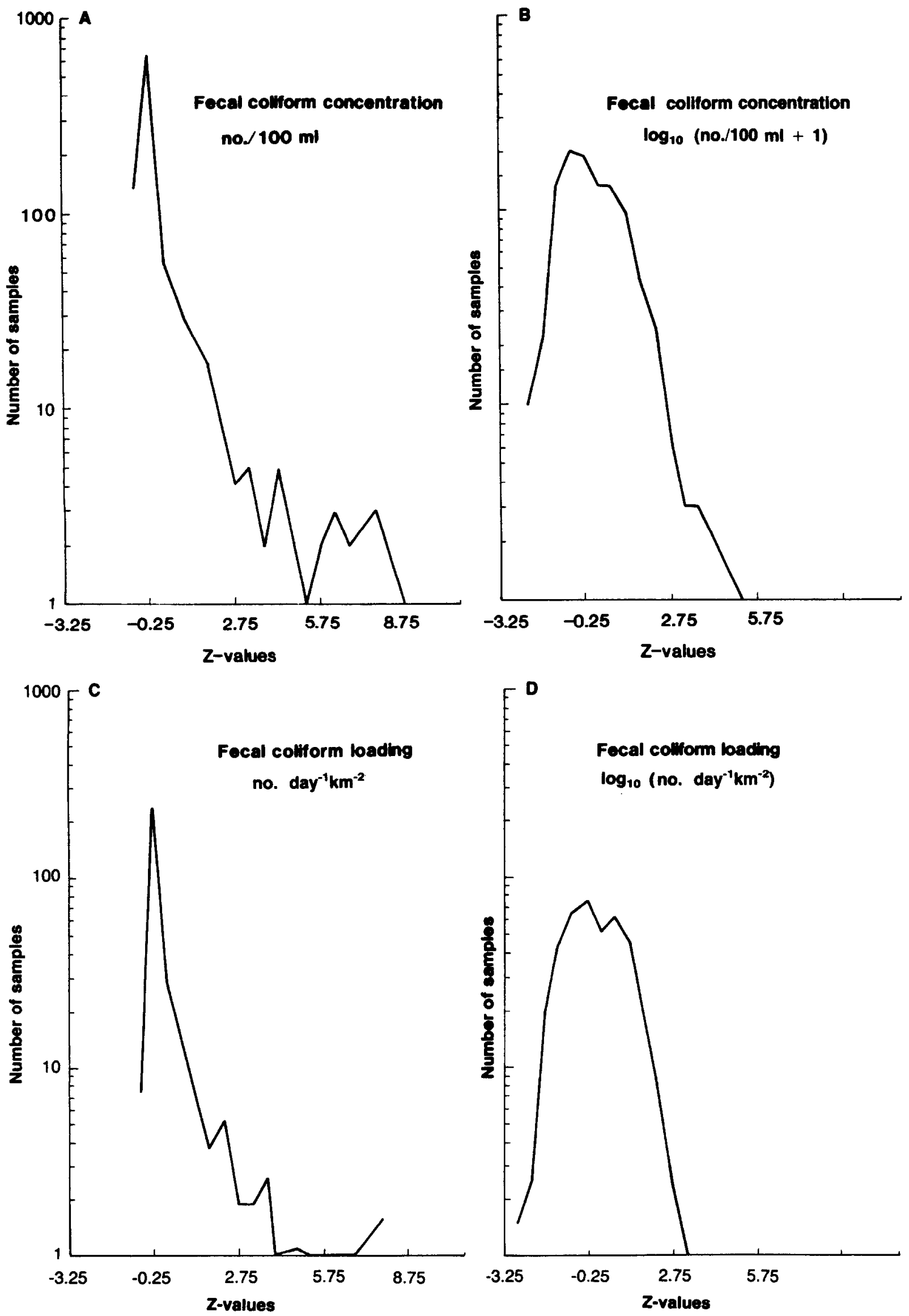

Fig. 1. Z-distributions for transformed and nontransformed FC counts and loadings: (A) FC counts not transformed; (B) FC counts transformed using $\log _{10}(F C+1)$; (C) FC loadings not transformed; and (D) FC loadings transformed using $\log _{10}\left(F C\right.$ number day $\left.^{-1} \mathrm{~km}^{-2}\right)$. 


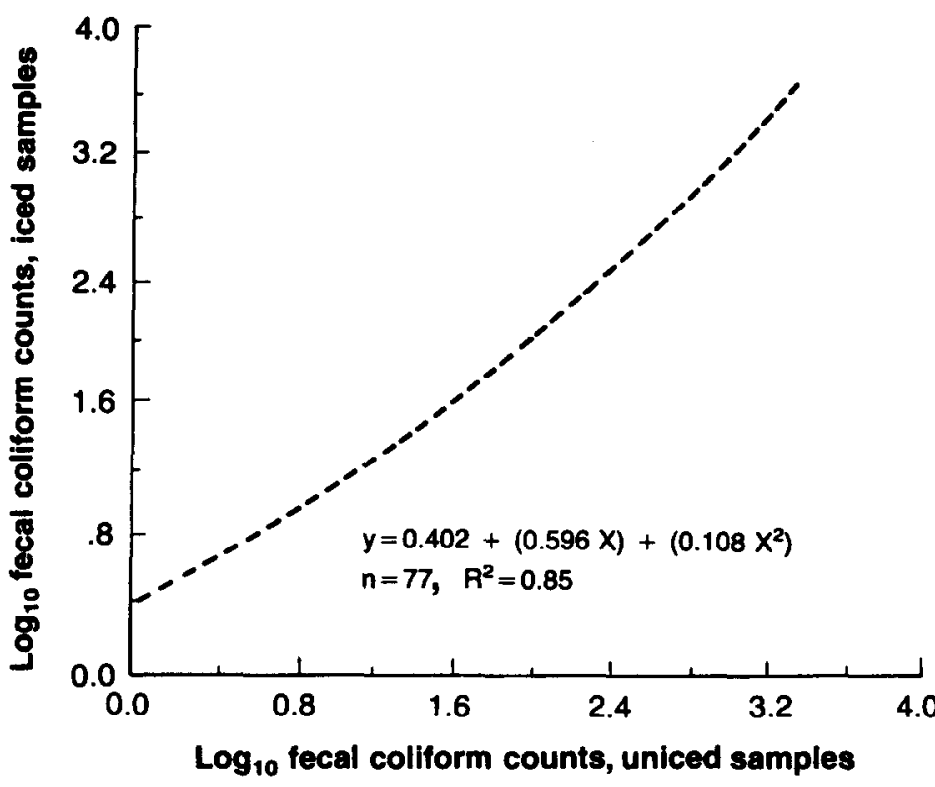

Fig. 2. Relationship of iced to uniced samples for FC counts.

exact dates of each season varied among watersheds because of the different flow regimes but were consistent from year to year for each watershed. Where the F-test was significant, the Least Significant Difference (LSD) test (Carmer and Swanson 1971) was used
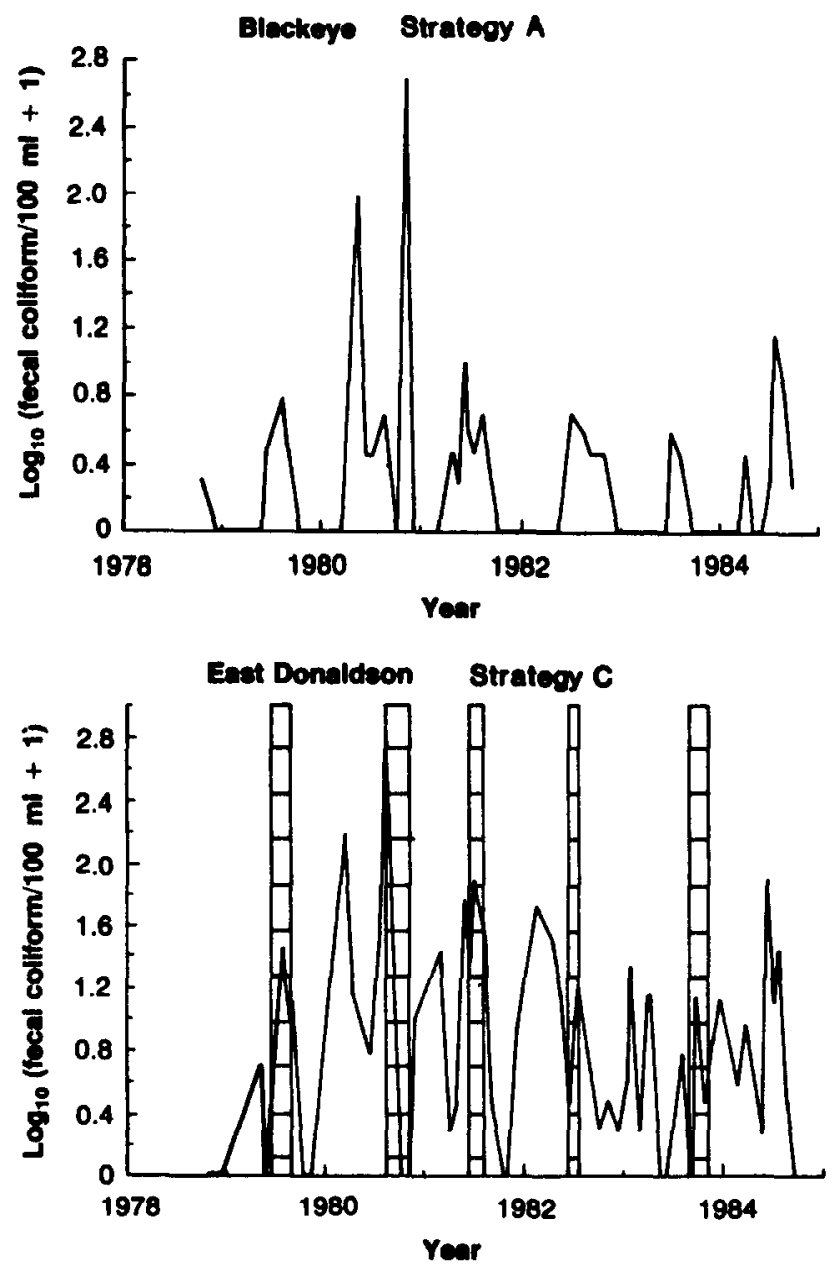

to determine the significance of differences among means.

Concentration data were also analyzed to determine the effect of cattle presence within the pasture on FC levels. A statistical design similar to that described above was used with cattle presence replacing season. Samples collected when the cattle were on the pastures were classified as "cattle present." The 3 samples immediately preceding cattle turnout on the pasture were classified as "cattle not present." All remaining samples were excluded from the analysis to minimize carryover effects from year to year. Watersheds with strategy A management were excluded from this analysis.

\section{Results and Discussion}

Effects of $\log _{10}$ Transformation on Standardized $Z$ Distributions

Both concentration and loading distributions were improved by $\log _{10}$ transformation as shown by plots of transformed and untransformed values (Fig. 1, a-d). Transformed data were used for all analyses.

\section{Comparison of Iced and Uniced Samples}

Paired iced and uniced samples were significantly different ( $P<0.001$-geometric mean FC counts on iced samples was $18 / 100 \mathrm{ml}$ as compared to $13 / 100 \mathrm{ml}$ for the uniced. This suggests that some FC organisms died during transit to the laboratory when the samples were not iced during the summer. Results of the icing experiment are in concert with those of McFeters and Stuart (1972). They observed a decline in numbers of $E$. coli in membrane filter chambers with increasing water temperature between $5^{\circ}$ and $25^{\circ} \mathrm{C}$. Hendricks and Morrison (1967) found that $E$. coli increased between $5^{\circ}$ and $10^{\circ} \mathrm{C}$ but declined between $10^{\circ}$ and $16^{\circ} \mathrm{C}$. Both
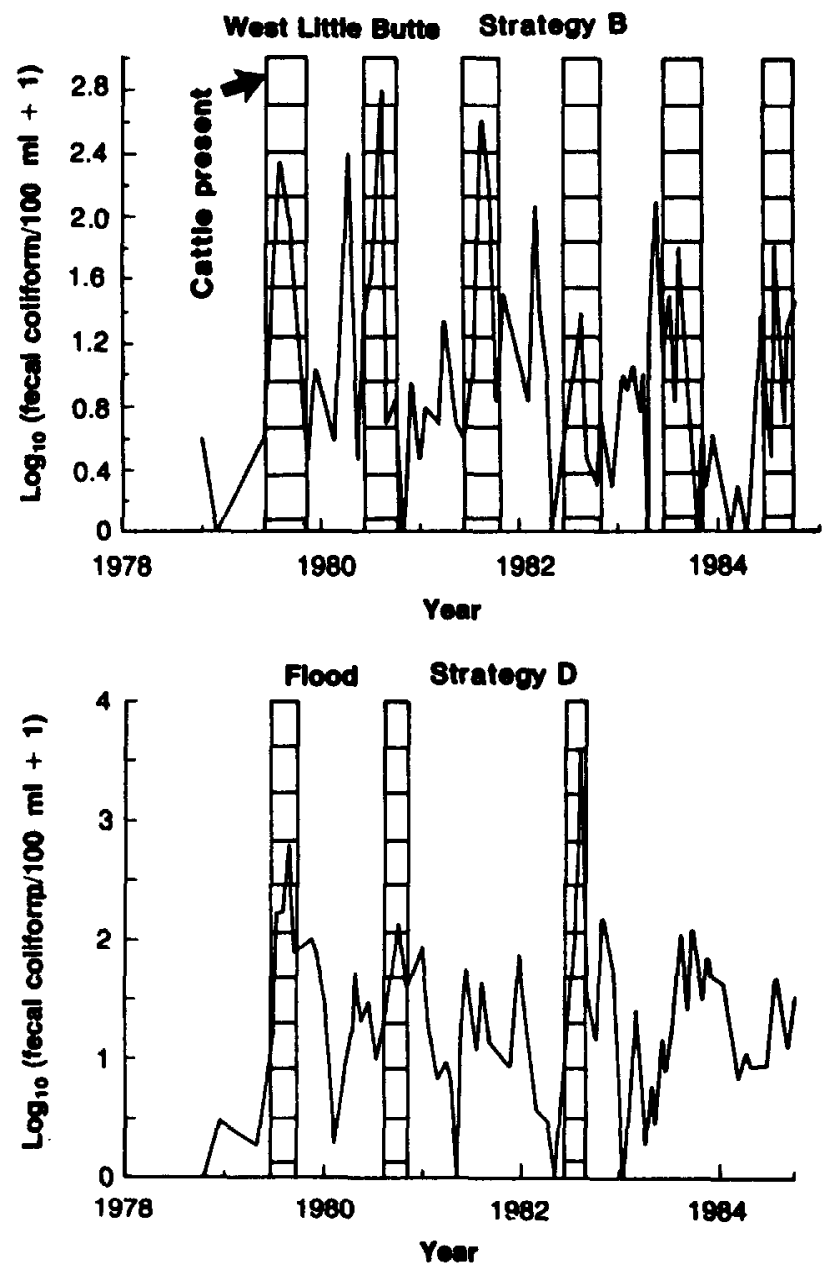

Fis. 3. Time trends of FC counts ( $\log _{10}$ FC counts +1$)$ for representative strategy $A, B, C$, and D watersheds. Grazing periods are indicated by vertical bars. 
studies were done with water from wildland streams. Although we did not measure temperatures of samples, the average mean weekly maximum for the 13 watersheds during the summer ( 21 June to 21 September) was $14.3^{\circ} \mathrm{C}$. On Flood, Keeney, Tinker, and Caribou, mean weekly maxima exceeded $16^{\circ} \mathrm{C}$. Placing the uniced samples in a cardboard box probably subjected them to even greater temperatures because the ambient temperature was generally greater than the steam temperature. Regression analyses provided a best fit quadratic equation between iced $(Y)$ and uniced $(X)$ samples:

$\mathrm{Y}=0.402+(0.596 \mathrm{X})+\left(0.108 \mathrm{X}^{2}\right) ; \mathrm{r}^{2}=0.85$ (Fig. 2).

This equation was used to adjust the 1 June to 30 September 1979-82, data.

Comparisons of FC Counts Among Graxing Strategies, Watersheds, Seasons, and Water Years

F-tests from the analysis of variance showed that range management strategy had a significant $(P<0.001)$ effect on FC concentration. The other main effects-watersheds within strategies, season, and water year-were significant at $P<0.001$. Interactions of strategy by season and strategy by water year were significant at $P<0.01$. The interaction of strategy by water year was significant at $P<0.02$, but the three-way interaction of strategy by season by water year was not significant.

Time trends of FC counts for representative watersheds of each strategy are presented to show differences among strategies, seasonal trends, year-to-year differences, and the relationships to presence or previous presence of livestock (Fig. 3).

Mean FC counts by strategy responded about as expected. Strategy A had the lowest mean FC count (2.9/100 ml) (Fig. 4);

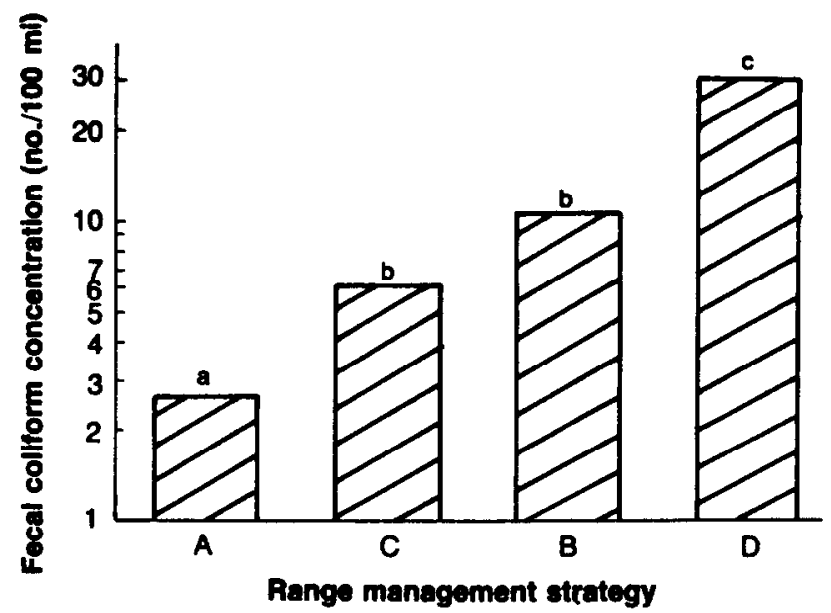

Fig. 4. Geometric mean FC concentrations by range management strategy, water years 1979-84. Bars with the same lower case letter are not significantly different at $\mathrm{P}<0.05$.

however, FC counts on 1 sampling occasion in Blackeye Creek exceeded $500 / 100 \mathrm{ml}$ (Fig. 3). Mean FC counts on strategies $C$ and $B$ watersheds were elevated significantly $(P<0.05)$ above those in strategy $A(5.7$ and $10.4 \mathrm{FC} / 100 \mathrm{ml}$, respectively) but there was no significant difference between strategy $C$ and strategy $B$. Average actual use on strategy $C$ and $B$ watersheds was similar -7.7 and 8.2 ha/ AUM, respectively. Counts in strategy $C$ watersheds were generally less than $200 / 100 \mathrm{ml}$ but on 1 sample occasion the count exceeded $300 / 100 \mathrm{ml}$. Watersheds with strategy $\mathrm{D}$ averaged 2.8 ha/AUM actual use and had significantly higher $(P<0.05)$ mean FC counts $(30.2 / 100 \mathrm{ml})$ than all other strategies. Counts in excess of $200 / 100 \mathrm{ml}$ were common. The maximum count on a strategy D watershed was $3,900 / 100 \mathrm{ml}$ and counts in excess of 2,000 were observed on 3 sampling occasions.

Frequency analyses (Fig. 5) showed that $50 \%$ of the samples in

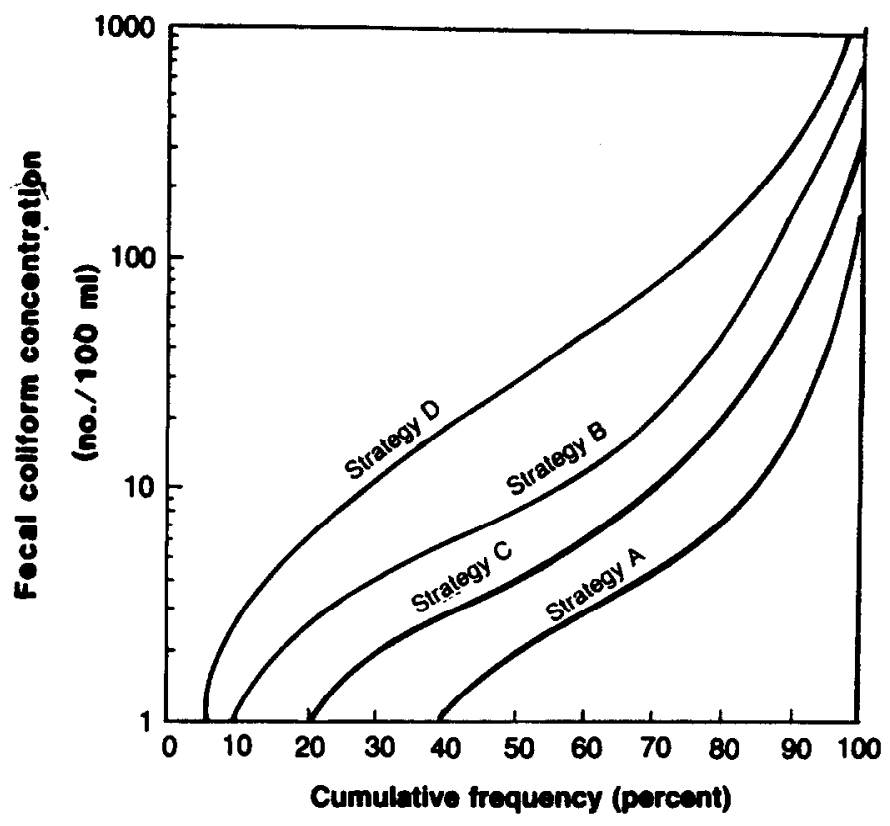

Fis. 5. Cumulative frequency distribution by strategy for FC data, water years 1979-84.

strategy A had less than $2 \mathrm{FC} / 100 \mathrm{ml}$. At the same level, C, B, and D strategies had less than $4.7,7$, and $29 \mathrm{FC} / 100 \mathrm{ml}$, respectively. Frequency comparisons among strategies were arrayed the same as the mean FC concentrations, A, C, B, and D.

Of the individual watersheds, those with strategy $A$ were most closely grouped together and had mean FC counts ranging from $2 / 100 \mathrm{ml}$ to slightly more than $4 / 100 \mathrm{ml}$ (Fig. 6). Strategy B was

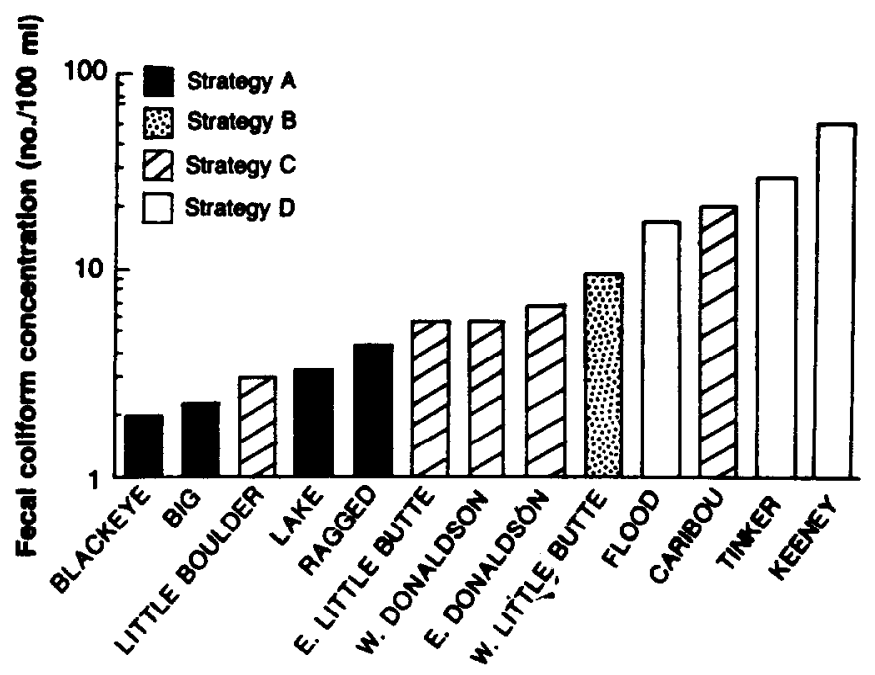

\section{Watershed}

Fig. 6. Geometric mean FC concentrations by watershed, water years 1979-84.

represented by only 1 watershed, West Little Butte. Counts on this watershed averaged $10.4 / 100 \mathrm{ml}$. Mean FC counts in strategy C ranged from $3 / 100 \mathrm{ml}$ to $20 / 100 \mathrm{ml}$ and resulted in 1 strategy $C$ watershed grouped in with the strategy $A$ watersheds and 1 grouped in with the strategy D watersheds. Mean counts in strategy D watersheds ranged from 16 to 54 .

Characteristics of individual watersheds played a major role in the degree of impact cattle had on water quality and also explain much of the variability observed among watersheds within strategies. Strategy A watersheds were primarily forested with no graz- 
ing. Uniformly low FC counts were anticipated. Fecal coliform counts in 3 of the strategy $C$ watersheds, East Little Butte, West Donaldson, and East Donaldson, responded to practices aimed at improving distribution of cattle with FC counts intermediate between A and B. Caribou (strategy C) had FC counts comparable to those in strategy $\mathrm{D}$ watersheds. Actual use was comparable to that of other strategy $C$ watersheds. Except for the lack of cultural treatments, this watershed was similar to the strategy D watersheds: it has stringer meadows with an open forest (ponderosa pine) that does not restrict cattle access to the stream. Also, slopes on portions of the watershed are steep enough to discourage cattle use, thereby encouraging animals to use stringer meadows. Little Boulder Creek, the strategy $C$ watershed with counts comparable to the strategy $A$ watersheds, is at a higher elevation and provides only limited access to the stream channel. Steep, well forested sideslopes adjacent to the stream channel discourage cattle use. Levels of FC in the single strategy B watershed were intermediate between strategies $C$ and $D$. Watersheds with the highest FC counts (primarily in strategy $D$ ) have distinct meadows with riparian zones that tend to attract cattle. The large meadows on Keeney and Flood watersheds also provided the best opportunity to achieve strategy $\mathrm{D}$ management because they were areas where cultural treatments, such as fertilization and seeding, could be used for achieving the best forage production. This resulted in a 3-fold greater stocking rate than strategy $B$ and $C$ watersheds. Tinker, the other strategy D watershed, has a small meadow (about 1 ha) approximately $400 \mathrm{~m}$ above the sample collection site. Cattle were observed to concentrate in this meadow on numerous occasions during the study.

Comparisons among seasons for mean FC concentrations (average across strategies, watersheds, and years) showed that counts were not significantly different for winter $(3.5 / 100 \mathrm{ml})$ and snowmelt runoff $(4.5 / 100 \mathrm{ml})$ seasons: however, summer concentrations $(18 / 100 \mathrm{ml})$ were significantly greater $(P<0.05)$ than concentrations during either winter or snowmelt runoff.

\section{Interactions of Strategy with Season and Water Year}

The seasonal response of the strategy D watersheds, as compared to the other 3 strategies, is responsible for the significant interaction of strategy by season in the analysis of variance. Counts of FC organisms on watersheds with strategies $A, B$, and $C$ generally increased from the winter season to the summer season (Fig. 7). On strategy $D$ watersheds, counts declined from levels significantly greater $(38 \mathrm{FC} / 100 \mathrm{ml})$ than those for any other strategy in

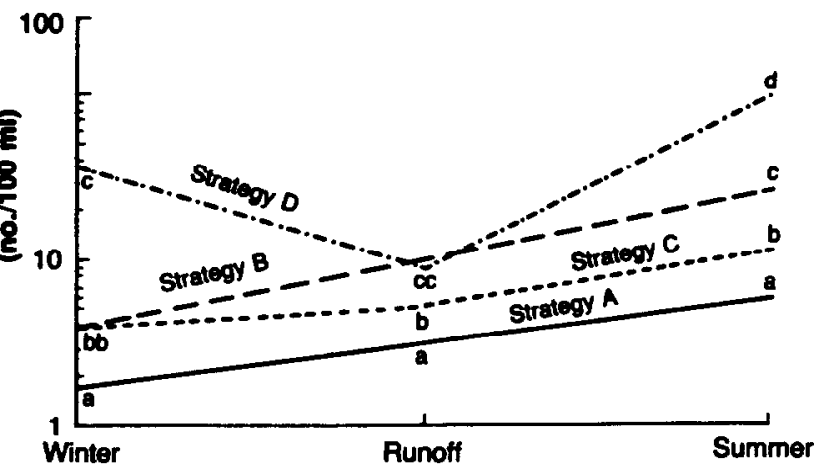

Fig. 7. Strategy by season interaction for geometric mean FC concentrations, water years 1979-84. Strategies within a season with the same lower case letter are not significantly different at $\mathrm{P}<0.05$.

the winter to the same level as strategy $B$ in the runoff season ( 9 $\mathrm{FC} / 100 \mathrm{ml}$ ). By summer, FC levels for strategy D were again greater than for any other strategy $(90 \mathrm{FC} / 100 \mathrm{ml})$. The LSD tests at $P<0.05$ show that $F C$ counts in the winter were arrayed as $A<B$
$=\mathrm{C}<\mathrm{D}$. During the runoff season, the array was $\mathrm{A}<\mathrm{C}<\mathrm{B}=\mathrm{D}$. The summer array was $A<C<B<D$.

Increasing counts during the summer are related to the presence of livestock in strategies B, C, and D. Summer wildlife activity probably accounts for the increased counts in the strategy $A$ watersheds. Walter and Bottman (1968) observed higher coliform and enterococci counts in a watershed closed to grazing and recreation than in a watershed open to the public in Montana. They attributed their results to greater wildlife activity in the closed watershed than in the open watershed.

Higher winter mean FC counts in strategy $D$ watersheds suggest a substantial carryover effect of cattle presence from summer into winter. We speculate that the elevated winter FC levels on strategy $D$ watersheds are related to the presence of fecal material in or near the stream channel. The differential response of the strategy D watersheds during the runoff season, as compared to the other strategies, is perplexing. Dilution may be a primary factor responsible for the reduced FC levels. Two of the 3 strategy D watersheds yield more water per unit area during snowmelt runoff than do the other watersheds.

The strategy by water year interaction showed that implementation of strategy D resulted in a general increase in FC concentrations during the period of study (Fig. 8). Fecal coliform counts on

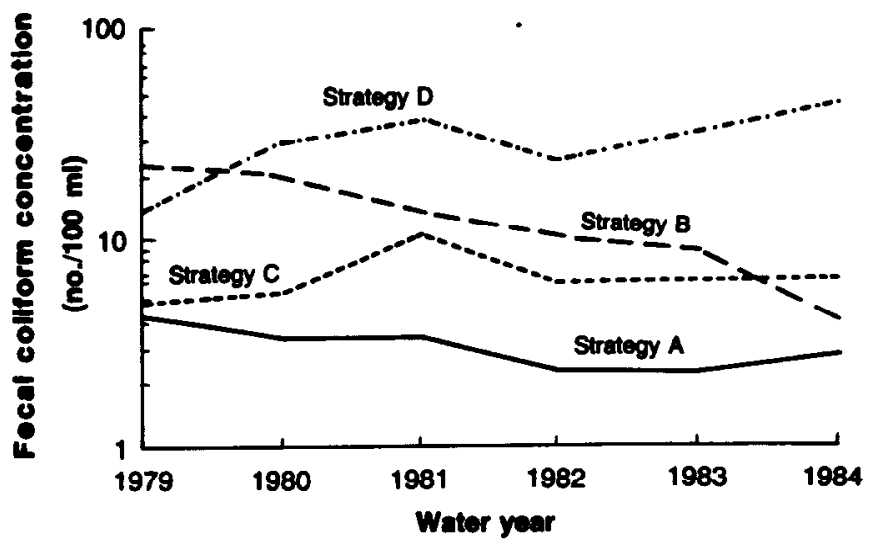

Fig. 8. Strategy by water year interaction for geometric mean FC concentrations, water years 1979-84.

strategy $\mathbf{C}$ watersheds, in contrast, were relatively uniform from year to year. Response of the single strategy $B$ watershed is a special case. Fecal coliform levels declined continually through the study period. We speculate that this decline was the result of a fence that caused livestock to gradually shift their use of this watershed. Prior to EVAL, West Little Butte was managed as a strategy B watershed. A small stringer meadow in the vicinity of the sample collection sites was readily accessible from downstream travel and feed areas. This meadow was not easily reached from other directions. After fences were constructed to achieve strategy $\mathbf{C}$ management of East Little Butte, the West Little Butte meadow was not as accessible to livestock. The West Little Butte watershed was still grazed, but the animals could not concentrate in the same meadow areas as they did prior to EVAL implementation-hence, the decline in FC levels.

\section{Effects of Cattle Presence on FC Concentrations}

Concentrations of FC organisms with cattle present were nearly 6 times greater than when cattle were absent $(34 / 100 \mathrm{ml}$ compared to $6 / 100 \mathrm{ml}$ ). This difference was significant at $P<0.0001$. The F-test for strategy and the cattle presence by strategy interaction were also significant at $P<0.0001$. Differences among years and the interaction of cattle presence with years were not significant. Comparison (LSD) tests of the means of the cattle presence by strategy 
interaction revealed that the difference between presence and absence of cattle was highly significant $(P<0.01)$ for all 3 strategies. The largest difference in FC counts between presence and absence occurred with strategy D $(246 / 100 \mathrm{ml}$ compared to $7 / 100 \mathrm{ml})$. Differences were lowest for strategy $C(15 / 100 \mathrm{ml}$ compared to $5 / 100 \mathrm{ml})$. Strategy $B$ was intermediate $(34 / 100 \mathrm{ml}$ with cattle present compared to $7 / 100 \mathrm{ml}$ with cattle absent).

\section{Fecal Coliform Loadings}

Analysis of variance showed that instantaneous loadings differed significantly $(P<0.01)$ among strategies, seasons, and water years. Interactions of season by strategy and season by water year were also significant $(P<0.01)$. The interaction of water year by

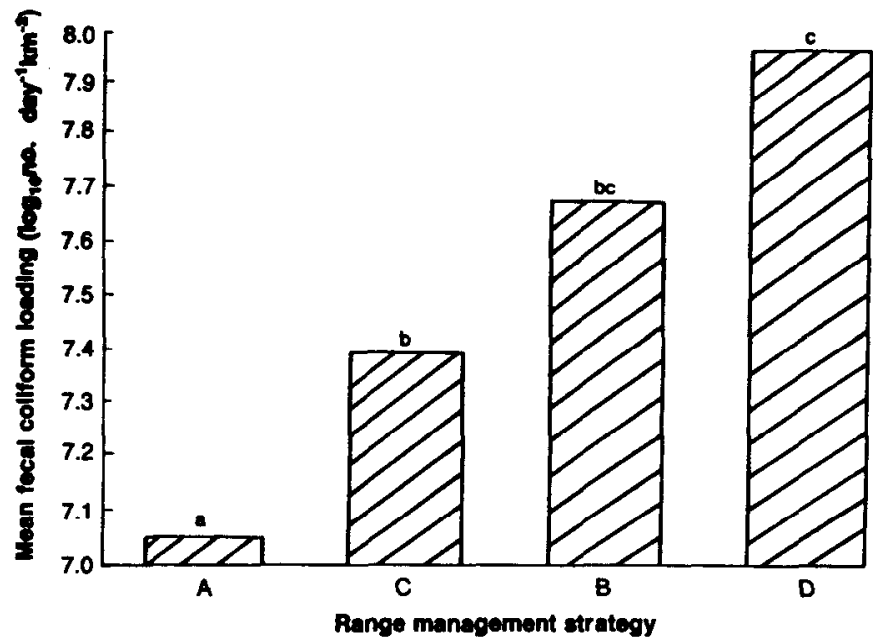

Fig. 9. Mean FC loadings by range management strategy, water years 1979-84. Bars with the same lower case letter are not significantly different at, $\mathrm{P}<0.05$.

strategy was not significant. Mean comparisons (LSD test) indicated that FC loading with strategy A was significantly $(P<0.05)$ lower than any other strategy (Fig. 9). Differences between strategies $\mathrm{C}$ and $\mathrm{D}$ were also significant. There were no significant differences in loadings between strategy $B$ and strategies $C$ and D.

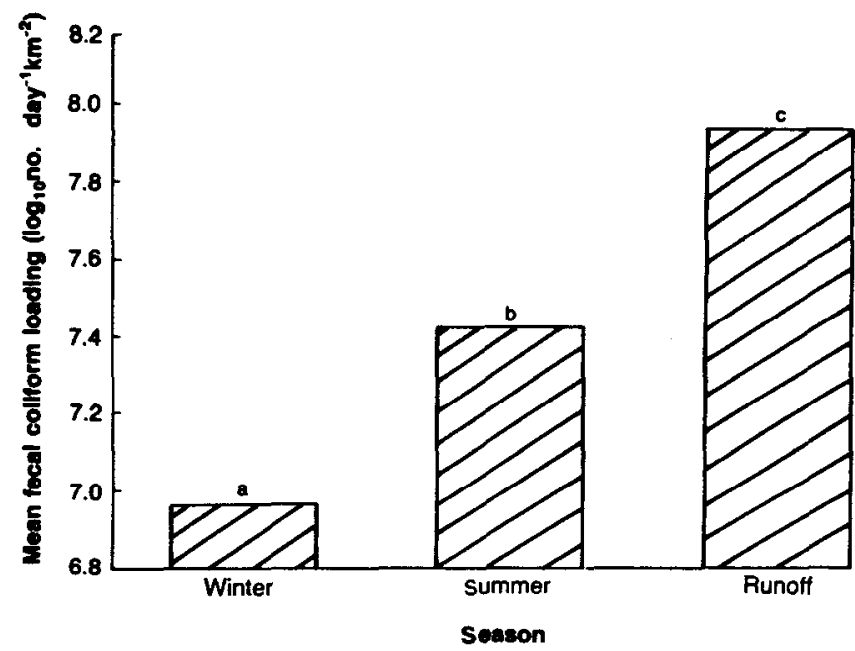

Fig. 10. Mean FC loadings by season, water years 1979-84. Bars with the same lower case letter are not significantly different at $\mathrm{P}<0.05$.

As expected, loadings were lowest for winter (Fig. 10). Snowmelt runoff produced the greatest loadings; approximately 10 times the output during the winter. Summer loadings were intermediate between and significantly different from winter and runoff periods. Skinner et al. (1974) found that although sample counts increase in the summer, the actual number of organisms was less than during runoff.
Response of strategy $B$ is the primary reason for the significance of the term for the strategy by season interaction in the analysis of variance. During the winter, loadings with strategy $B$ were the same as for strategy C(Fig. 11). In the runoff season, loadings with

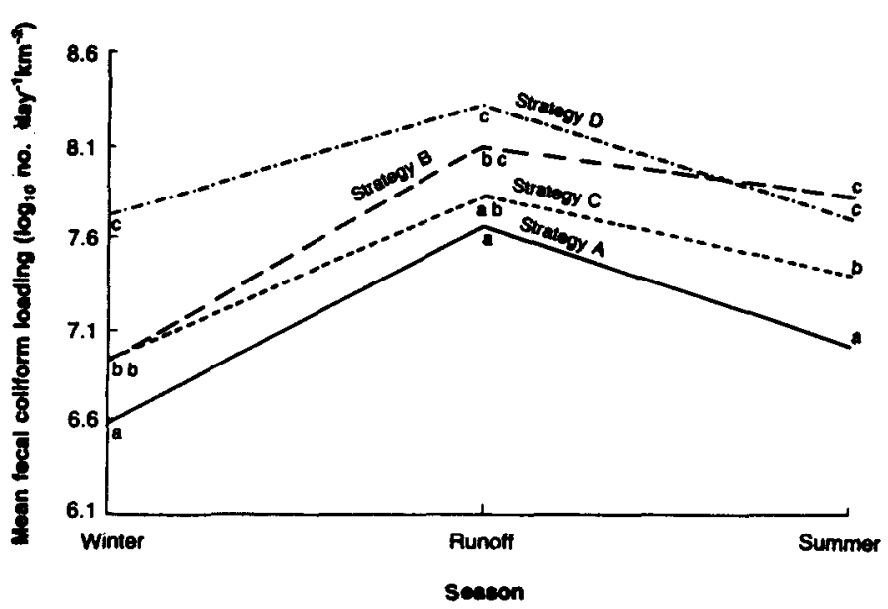

Fig. 11. Season by strategy interaction for FC loadings, water years 1979-84. Strategies within a season with the same lower case letter are not significantly different at $\mathrm{P}<0.05$.

strategy $B$ were the same as those with strategies $C$ and $D$; in the summer, loadings with strategy $B$ were the same as those with strategy $D$. The strategy $A$ loadings were lower than those for all other strategies during the winter and summer. Loadings were higher with strategy $D(P<0.05)$ than with any strategy during winter and spring runoff seasons. Strategy $C$ was significantly different from strategies $A$ and $D$ during the winter and summer runoff periods.

\section{Conclusions}

The presence of livestock on the study watersheds exerted a significant effect on the bacterial quality of the surface waters. We have demonstrated a definite relationship between the presence or absence of livestock and FC counts. Intensified grazing management is manifested in a greater than 10 -fold increase in average FC levels between strategies A and D. Maximum FC levels on strategy $D$ watersheds were 4 to 6 times greater than those of the other strategies. Although FC counts in excess of $200 / 100 \mathrm{ml}$ were observed on several samples from strategy D watersheds, sample frequency was not sufficient for us to compare with Oregon State water quality standards.

If we were to have predicted the array of $\mathrm{FC}$ counts among strategies, given similar watershed characteristics, it would have been $\mathrm{A}<\mathrm{C}<\mathrm{B}<\mathrm{D}$. But, results do not fit this pattern; mean FC levels were arrayed $A<B=C<D$. However, when we compared the strategies among seasons, FC counts for the summer season fit the predicted array.

Low FC counts in streamflow from the strategy $A$ watersheds suggested a low level of stream contamination by wildlife. Other studies (Kunkle and Meiman 1968, Skinner et al. 1974, Jawson et al. 1982, Mullen 1983) also show that watersheds from which livestock have been excluded have lower FC counts than grazed watersheds.

One aim of improved distribution through fencing and water developments under strategy $C$ was to reduce animal contact with the stream and to lower FC counts. Although mean FC counts were not significantly different between strategies $B$ and $C$, significantly lower FC counts for strategy $C$ in the summer suggest that improvement of livestock distribution with this strategy resulted in reduced FC counts. However, there was only one strategy B watershed and verification of this finding requires further study. 
The FC levels in the strategy $D$ watershed are at the upper end of the array because the cultural improvements result in greater forage production and increased stocking rates. The type of watershed selected for this strategy is also a factor. Two of the 3 watersheds managed with strategy $D$ have large meadow areas where the type of cultural practices prescribed for this strategy could be implemented. Therefore, strategy D presented the greatest opportunity for animal contact with the stream ecosystem.

Results provide evidence that livestock removal may not provide an immediate solution to problems with bacterial contamination of streamwater. Elevated counts of FC organisms in the strategy D watershed in the winter season (35/100 ml compared to $5 / 100 \mathrm{ml}$ for strategies $A, B$, and $C$ ) and values in excess of $10^{8}$ organisms day $^{-1} \mathrm{~km}^{-2}$ during the runoff period indicate that organisms live into and through the winter period in animal feces, sediment, and soil. This is consistent with the results of several observers (Kunkle and Meiman 1968, Clemm 1977, Stephenson and Street 1978, Jawson et al. 1982). Elevated winter FC counts on strategy D watersheds are probably a result of continued transport from fecal material deposited directly in the stream channel during the summer. Streamflow during the winter would not be expected to change substantially from the summer period. During the spring runoff period, 2 other transport mechanisms come into play. Overland flow during the spring carries fecal material near the stream channel into the stream. Higher streamflow during spring runoff involves a greater area of the stream channel than during the summer, thereby reaching and transporting fecal material previously out of reach of the low summer flows. Kunkle and Meiman (1968) reached the same conclusion. Sediments also may be a significant source of carryover because nutrients and more stable temperatures of the stream bottom provide a more favorable environment for FC organisms than the surface water (Van Donsel and Geldreich 1971). Populations in sediments may be 100 to 1,000 times greater than in surface waters (Hendricks and Morrison 1967, Kunkle 1970, Van Donsel and Geldreich 1971).

Levels of FC organisms in streamflow appear to be more closely related to watershed characteristics that determine where livestock are likely to concentrate than to stocking rates. Caribou (strategy C) had FC counts similar to those of the strategy D watersheds despite actual use that was $67 \%$ less. This watershed has meadows similar to those on strategy $D$ watersheds.

\section{Literature Cited}

Bohn, C.C., and J.C. Buckhouse. 1985. Coliforms as an indicator of water quality in wildland streams. J. Soil Water Conserv. 40:95-97.

Carmer, S.G., and M.R. Swanson. 1971. Detection of differences between means: a Monte Carlo study of five pairwise multiple comparison procedures. Agron. J. 63:940-945.

Clemm, D. 1977. Suvival of bovine enteric bacteria in forest streams and animals wastes. M.S. thesis. Central Washington Univ., Ellensburg. 20 p.

Coltharp, G.B., and L.A. Darling. 1973. Livestock grazing-a nonpoint source of water pollution in rural areas? p. 341-358. In: V.H. Jewell, and R. Swan (eds.). Symp. proc., Rural Environ. Engineering, Univ. Vermont. Univ. Press New England, Hanover, N.H.

Doran, J.W., and D.M. Linn. 1979. Bacteriological quality of runoff water from pastureland. Appl. Environ. Microbiol. 37:985-991.

Fowler, W.B., J.D. Helvey, and C. Johnson. 1979. Baseline climatic and hydrologic relationships for the High Ridge Evaluation Area. USDA Forest Serv. Gen. Tech. Rep. PNW-91, 17 p. Pac. Northwest Forest and Range Exp. Sta., Portland, Ore.
Gary, H.L., S.R. Johnson, and S.L. Ponce. 1983. Cattle grazing impact on surface water quality in a Colorado Front Range stream. J. Soil Water Conserv. 38:124-128.

Geldrich, E.E. 1970. Applying bacteriological parameters to recreational water quality. J. Amer. Water Works Ass. 62:113-120.

Helvey, J.D., W.B. Fowler, G.O. Klock, and A.R. Tiedemann. 1976. Climate and hydrology of the Entiat Experimental Forest watersheds under virgin forest cover. USDA Forest Serv. Gen. Tech. Rep. PNW-42, 18 p. Pac. Northwest Forest and Range. Exp. Sta., Portland, Oregon.

Hendricks, C.W., and S.M. Morrison. 1967. Multiplication and growth of selected enteric bacteria in clear mountain stream water. Water Res. 1:567-576.

Jawson, M.D., L.F. Elliott, K.E. Saxton, and D.H. Fortier. 1982. The effect of cattle grazing on indicator bacteria in runoff from a Pacific Northwest watershed. J. Environ. Qual. 11:621-627.

Kunkle, S.H. 1970. Sources and transport of bacterial indicators in rural streams. p. 105-132. In: Symp. proc. on the interdisciplinary aspects of watershed management. Montana State Univ, Bozeman.

Kunkle, S.H., and J.R. Meiman. 1968. Sampling bacteria in a mountain stream. Hydrology Pap. No. 28. Colorado State Univ., Fort Collins.

McFeters, G.A., and D.G. Stuart. 1972. Survival of coliform bacteria in natural waters: field and laboratory studies with membrane filter chambers. Appl. Microbiol. 24:805-811.

Mullen, V.J. 1983. The effect of cattle grazing on the microbiological water quality of mountain streams. M.S. thesis. Central Washington Univ., Ellensburg.

National Oceanozraphic and Atmospheric Administration. 1984. Climatological data, annual summary, Oregon, 1984. Vol. 90, No. 13. National Climatic Data Center, Asheville, N.C.

Rand, M.C., A.E. Greenbers, and M.J. Tarns. 1975. Standard methods for the examination of water and wastewater. 14th ed. American Public Health Ass. Washington, D.C. 1193.

Sanderson, H.R., and T.M. Quigley. 1984. EVAL-a coordinated and comprehensive approach to range management. p. 84-85. In: Proc. 1984 Pacific Northwest range management short course. Range watersheds, riparian zones, and economics: interrelationships in management and use. Oregon State Univ., Corvallis.

Skinner, Q.D., J.C. Adams, P.A. Rechard, and A.A. Beetle. 1974. Effect of summer use of a mountain watershed on bacterial water quality. J. Environ. Qual. 3:329-335.

Skinner, Q.D., J.E. Speck, Jr., M. Smith, and J.C. Adams. 1984. Streamwater quality as influenced by beaver within grazing systems in Wyoming. J. Range Manage. 37:142-146.

Snedecor, G.W., and W.G. Cochran. 1967. Statistical methods. Iowa State University Press, Ames.

State of Orezon. 1986. Regulations relating to water quality control in the State of Oregon. Sections from Oregon Administrative Rules Chapter 340. Dep. Environ. Qual., Salem.

Steel, R.G.D., and J.H. Torrie. 1960. Principles and procedures of statistics. McGraw-Hill, N.Y.

Stephenson, G.R., and L.V. Street. 1978. Bacterial variations in streams from a southwest Idaho. rangeland watershed. J. Environ. Qual. $7: 150-157$.

Stephenson, G.R., and R.C. Rychert. 1982. Bottom sediment: a reservoir of Escherichia coli in rangeland streams. J. Range Manage. 35:119-123.

U.S. Environmental Protection Agency. 1976. Quality criteria for water, Iuly 1976. Fecal coliform bacteria. U.S. Environ. Protect. Agency, Washington, D.C. p. 42-50.

Van Donsel, D.J., and E.E. Geldreich. 1971. Relationships of Salmonellae to fecal coliforms in bottom sediments. Water Res. 5:1079-1087.

Van Donsel, D.J., E.E. Geldrelch, and N. Clarke. 1967. Seasonal variations in survival of indicator bacteria in soil and their contribution to stormwater pollution. Appl. Microbiol. 15:1362-1370.

Walter, W.G., and R.P. Bottman. 1968. Microbiological and chemical studies of an open and closed watershed. J. Environ. Health 30:157-163. 